\title{
COMPARISON OF SERUM LEVELS OF VITAMIN A, VITAMIN D AND ZINC IN ACUTE LOWER RESPIRATORY TRACT INFECTIONS IN CHILDREN
}

\section{Paediatrics}

Anil Sharma

Shalini Dash*
Senior Resident, Sanjay Gandhi Post Graduate Institute of Medical Sciences, Raebareli Road, Lucknow, India

Senior Resident, Sanjay Gandhi Post Graduate Institute of Medical Sciences, Raebareli Road, Lucknow, India *Corresponding Author

\section{ABSTRACT}

Aim: Acute lower respiratory infections (ALRIs) are global problem, and there are large differences in mortality rates between developed and developing countries. Deficiency of micronutrients may increase the risk of ALRI. A case-control study was conducted to assess the associations between vitamin A, vitamin D, zinc and ALRI in eastern part of Indian children.

Methods: Children aged 1-60 months hospitalizes with ALRI (cases, $\mathrm{N}=51$ ) were matched to controls on age, sex and socio-economic status ( $\mathrm{N}$ =31). The mean Serum levels of Vitamin A, Vitamin D (25-hydroxy vitamin D) and Zinc in cases and controls was compared using student's paired t-test and compared the severity of pneumonia with these levels.

Results: Mean (SD) level of serum vitamin A, vitamin D and zinc in the cases were $17.08( \pm 10.53) \mu \mathrm{g} / \mathrm{dl} ; 13.91( \pm 2.99) \mathrm{ng} / \mathrm{ml} \mathrm{and} 61.51( \pm 13.84)$ $\mu \mathrm{g} / \mathrm{dl}$, respectively. The serum vitamin A, vitamin D and zinc levels were significantly lower in cases of ALRI as compared to controls ( $<<0.001)$. In our study serum vitamin D level was significantly associated with severity of ALRIs $(\mathrm{p}=0.042)$, and mean level of serum vitamin A was significantly low in case of severe pneumonia as compared to pneumonia $(\mathrm{p}=0.011)$

Conclusion: Vitamin A, vitamin D and zinc status was associated with childhood ALRI in matched case-control study in eastern part of India. Randomized trials may establish whether interventions to improve theses micronutrients status can reduce the burden of ALRI in children.

\section{KEYWORDS}

Case-control study, developing country, Acute lower respiratory tract infections, Vitamin A, Vitamin D, and Zinc.

\section{INTRODUCTION-}

Acute lower respiratory infections (ALRIs) remain a persistently health issue in indigenous communities. Acute lower respiratory infections (ALRIs) are global problem, and there are large differences in mortality rates between developed and resource-poor countries. Every year, 1.4-1.6 million young children die from this infection and up to $13 \%$ of roughly 155 million episodes are severe enough to warrant hospital admission. Respiratory-tract infections are caused by a mixture of viral and bacterial pathogens and are particularly common in low birth weight children and children exposed to poor nutritional conditions, indoor air pollution, low socioeconomic status, overcrowded living conditions, HIV co-infection, and low immunisation coverage. ${ }^{1}$ In developing countries vitamin A, vitamin D and zinc supplementation has been studied for prevention and treatment of acute lower respiratory tract infection. Limited study available on the level of these micronutrients in children who suffering from ALRIs. Richard et al., (1999) explained the vitamin A deficiency is a major cause of childhood morbidity and mortality in developing countries. ${ }^{2}$ Hyakinci et al., (1997) reported that deficiency of serum vitamin $\mathrm{A}$ is one of the widespread public health problem among preschool children in developing countries. Serum vitamin A and betacarotene levels in 56 pre-school age children who had recurrent acute respiratory infections (ARI) or recurrent diarrhoea were determined by a UV/VIS spectrometer. The results obtained were compared with 35 healthy pre-school age children. Serum vitamin A levels in children with ARI's were found significantly lower than the control group and beta-carotene $(81.63+/-15.41$ micrograms/dL) levels in children with recurrent diarrhoea were also found significantly lower than the control group $(58.14+/-9.07$ micrograms/dL and $131.43+/-22.38$ micrograms/dL, respectively, $\mathrm{p}<0.001$ ). ${ }^{3}$ Swami et al., (2007) studied the impact of mass supplementation of vitamin A on morbidity due to diarrhea and ARI and xeropthalmia. ${ }^{4} L a a k s i$ et al., (2007) a crosssectional study of 800 military recruits in Finland stratified men by serum vitamin D levels. Those recruits with lower vitamin D levels lost significantly more days from active duty secondary to upper respiratory infections than recruits with higher vitamin D levels (above $40 \mathrm{nmol}$ ). ${ }^{5}$ Roth et al., (2010) study conducted in Bangladesh on vitamin D status and acute lower respiratory infection in early childhood in Sylhet. In this study children aged 1-18 months hospitalized with ALRIs (cases) were individually matched to controls on age, sex, and village ( $\mathrm{N}=25$ pairs). The mean serum 25hydroxyvitamin D concentration $[25(\mathrm{OH}) \mathrm{D}]$ in cases and controls was

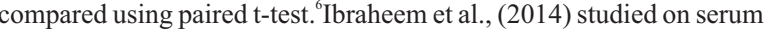
zinc levels in hospitalized children with acute lower respiratory infections in the north-central region of Nigeria. It was a comparative cross-sectional hospital based study involving 120 children aged two months to five years with ALRI recruited as subjects, and 120 ageappropriate controls without ALRI. The mean (SD) serum zinc level in subjects with ALRI of $18.7(11.8) \mu \mathrm{g} / \mathrm{dl}$ was significantly lower than the corresponding value of 53.1(18.5) $\mu \mathrm{g} / \mathrm{dl}$ recorded in the controls, $(\mathrm{p}=0.001)$. Luabeya et al., (2007) studied the effect of zinc or multiple micronutrient supplementations to reduce diarrhoea and respiratory disease in South African children.

In the current study, we estimate the serum levels of vitamin A, vitamin $\mathrm{D}$ and zinc in young children who hospitalized with diagnosis of ALRIs. The main objective was to observe the serum levels of vitamin A, Vitamin D and zinc in children with pneumonia (ALRI). In the present study, we also correlate the levels of vitamin A, Vitamin D and zinc with severity of ALRIs.

\section{MATERIALAND METHODS-}

This was open, observational, cross-sectional and comparative casecontrol study to assess the serum levels of vitamin A, vitamin D and zinc in children who suffered from acute lower respiratory tract infection and correlation of severity with serum levels of these micronutrients. Patients satisfying inclusion and exclusion criteria as mentioned below were enrolled for the study. Inform consent was taken from the parents to participate in to the study.

\section{ENROLMENT-}

Children less than 5 years of age ( 1 month to 60 months) was admitted in paediatric ward as a case of acute lower respiratory tract infection. Cases were diagnosed by attending Pediatric physician, the case of acute lower respiratory infection was diagnosed on basis of clinical signs and symptoms for considering inclusion in the study. In cases (ALRI) rapid breathing defined according to WHO criteria. The control population was comprised of children less than age 5 years without respiratory symptoms who were receiving care in out-patient or came for immunization.

The physician diagnosed acute lower respiratory tract infection on the basis of cough and fast breathing. Patient having cough associated with fast breathing as per age of patient like more than 60 breath per minute for age less than 2 months, 50 breaths per minute for age of 3 months 12 months and 40 breaths per minute for age more than 1 year. Patient complaining of cough usually associated with crepitation, sometimes wheeze, bronchial breath sounds or pleural rub on auscultation. The severity indicators of acute lower respiratory tract infection were inability to drink or feed, marked lethargy or irritability, nasal flare, cyanosis, altered sensorium, convulsions, respiratory effort fatigue, chest retraction (subcostal, intercostal or suprasternal), rhonchi etc. 


\section{Inclusion Criteria}

1. Fever (Temperature $\geq 37.6^{\circ} \mathrm{C}$ ) and

2. cough and/or difficulty breathing for less than 2 weeks and

3. Rapid respiratory rate for age by WHO criteria ( $\geq 60$ breaths per minute in infants younger than 2 months of age, $\geq 50$ breaths per minute for infants from 2 to 12 months of age, and $\geq 40$ breaths per minute for children 1 to 5 years of age)

Additional Criteria for severity assessment

1. Grunting / nasal flaring / chest in-drawing (supra sternal, sub costal or inter costal) / rhonchi (after rule out asthma) / crackles / stridor/ unconscious / drowsiness / lethargy / inability to drink or breast feed, and/or

2. Suggestive chest radiograph (consolidation / focal infiltration / minimal pleural effusion / collapse lung)

\section{Exclusion Criteria}

1. Children with co-existing Congenital heart disease

2. Chronic lung diseases like bronchiectasis, asthmatic bronchitis, hyper-reactive airway diseases and chronic cough more than 2months duration

3. Children with Immuno deficiency diseases

4. Children who undergone small bowel surgery

5. Foreign body aspiration

6. Protein energy malnutrition (Grade III/IV)

7. Patients, who had received vitamin A and vitamin D in last 6 months and zinc within one month

In our study we classify the cases of ALRIs as pneumonia or severe pneumonia by following signs or symptoms.

\begin{tabular}{|l|l|}
\hline Classify as & Signs and symptoms \\
\hline Pneumonia & $\begin{array}{l}\text { Fever, } \\
\text { Cough, and } \\
\text { Tachypnea (According to WHO) }\end{array}$ \\
\hline $\begin{array}{l}\text { Severe } \\
\text { Pneumonia }\end{array}$ & $\begin{array}{l}\text { Grunting / nasal flaring / } \\
\text { Chest in-drawing (supra sternal, sub costal or inter } \\
\text { costal) / } \\
\text { Rhonchi / crackles / stridor/ } \\
\text { Unconscious / drowsiness / lethargy / } \\
\text { Inability to drink or breast feed }\end{array}$ \\
\hline
\end{tabular}

\section{Sample size -}

A total of $121(n=121)$ patient clinical diagnosed and hospitalized as case of acute lower respiratory tract infection. Under 51 patients fulfil the inclusion criteria and treatment received before admission was noted like antibiotics, nebulization, mucolytic, bronchodilator. Total 43 patient was not met inclusion criteria and 27 patient refuse to participate in the study and 31 children were taken as control with matched age and sex. Control group have not any features suggestive of acute lower respiratory tract infections, they were treated on the OPD based and not had major clinical illness.

\section{Clinical Profile and Investigations -}

The clinical history, examinations and relevant investigations as per need to establish diagnosis of ALRIs, information were recorded in a standard-proforma.

1. Detailed history

2. Anthropometry

3. Physical examination (General and systemic)

4. Investigations (Complete blood count, ABGA, Chest X-ray, Blood cultures)

5. Serum vitamin A, vitamin D and zinc estimation.

\section{Collection of samples -}

Taking all aseptic precautions, about $5 \mathrm{ml}$ of blood was drawn by venipuncture from a peripheral vein, transfer to a plain vial. Serum was separated from the blood sample immediately by centrifugation before hemolysis of blood and serum was stored in separate de-ionized vials in freezer.

Measurement of serum level of vitamin A, vitamin D and Zinc

\begin{tabular}{|l|l|}
\hline Micronutrients & Method \\
\hline Vitamin A & Spectrophotometric Method \\
\hline Vitamin D & ELISA kit Method \\
\hline Zinc & Atomic Absorption Spectroscopy \\
\hline
\end{tabular}

RESULTS-

Fifty one children were enrolled as they satisfied the inclusion criterion and willing to participate in the study. Thirty one age and sex matched children were taken as control. In our study there was no significant difference in age distribution between case and control groups $(p=0.967)$. Infants $(<12$ months $)$ constituted $72.5 \%$ of cases and $77.5 \%$ of control.In cases, mean $( \pm 1 \mathrm{SD})$ age was $12.45( \pm 13.69)$ months and in control, it was $12.03( \pm 13.29)$ months. Both groups were comparable for the age. Male to female ratio in case and control groups were $1.2: 1$ and 1.4:1, respectively. In case and control groups, sex distribution was homogenous $(\mathrm{p}=0.780)$. In our study there was homogenous distribution of socioeconomic status in study populations $(p=0.835)$. Clinical features of case group - $100 \%$ children had Fever, cough and tachypnea. $74.5 \%$ children had difficulty in breathing, feeding difficulty was present in $52.9 \%$ cases and $17.6 \%$ presented to us with altered sensorium. Chest in-drawing was present in $49 \%$ of cases, $31.4 \%$ cases of ALRI had wheezing. $58.8 \%$ children had severe pneumonia and abnormal chest X-ray found in $72.5 \%$ cases.

Table 1 depicts low serum vitamin A, vitamin D and zinc levels in cases and control. Among the cases $23(45.1 \%)$ children had low serum vitamin A and among controls, only $3(9.7 \%)$ children had low serum vitamin A. There was significant difference of serum vitamin A levels between case and control $(\mathrm{p}=0.001)$, [Reference value for $0-6$ years is 11.3-64.7 $\mu \mathrm{g} / \mathrm{dl}]^{9} .18(35.3 \%)$ children had low serum vitamin D levels $[<12 \mathrm{ng} / \mathrm{ml}]^{10}$. In control group, only $4(12.9 \%)$ children had low serum vitamin D levels $(\mathrm{p}=0.026)$, and $31(60.8 \%)$ children had low levels of serum zinc[Normal 66 to $110 \mu \mathrm{g} / \mathrm{dl}]^{11}$ butincontrols, $10(32.3 \%)$ children had low serum zinc levels $(\mathrm{p}=0.015)$.

Table 2 shows the comparison of serum vitamin A, vitamin D and zinc values in study populations.

a) Mean vitamin A value for case group was $17.08( \pm 10.53) \mu \mathrm{g} / \mathrm{dl}$ and for control group was $42.98( \pm 21.98) \mu \mathrm{g} / \mathrm{dl}$. The mean serum vitamin A level was significantly low in the children with ARI ( $p$ $<0.001)$.

b) Mean vitamin D value for case group was $13.91( \pm 2.99) \mathrm{ng} / \mathrm{ml}$ and for control group was $19.38( \pm 7.83) \mathrm{ng} / \mathrm{ml}$. The mean serum vitamin D level was significantly low in the children with ARI ( $p$ $<0.001)$.

c) Mean zinc value for case group was $61.51( \pm 13.84) \mu \mathrm{g} / \mathrm{dl}$ and for control group was $74.60( \pm 17.30) \mu \mathrm{g} / \mathrm{dl}$. The mean serum zinc level was significantly low in the children with ARI $(\mathrm{p}<0.001)$.

Table 3 depicts Serum vitamin A, Vitamin D and zinc levels according to severity of ALRIs. $46.7 \%$ cases of severe pneumonia had low serum vitamin A levels, while the corresponding figure for cases of pneumonia was $42.9 \%$; the difference being statistically insignificant. $(p=0.788) .46 .7 \%$ cases of severe pneumonia had low serum vitamin D level, while the figure was $19.1 \%$ for pneumonia cases $(p=0.042)$. Similarly, $53.3 \%$ case of severe pneumonia had low serum zinc level, while $71.4 \%$ cases of pneumonia had low serum levels. There was no significant difference of serum zinc levels between severe pneumonia and pneumonia cases $(\mathrm{p}=0.193)$

Table 4 depicts mean level of serum vitamin A, vitamin D and zinc in cases of severe pneumonia and pneumonia. The mean level of serum vitamin A is significant low in case of severe pneumonia as compared to pneumonia $(\mathrm{p}=0.011)$

Table 1. Comparison of low serum vitamin A, vitamin D and zinc levels in study group

\begin{tabular}{|l|l|l|l|l|l|}
\hline \multirow{2}{*}{ Micronutrients } & \multicolumn{3}{|l|}{ Group } & \multirow{2}{*}{ p value } \\
\cline { 2 - 5 } & Case & \multicolumn{3}{l|}{ Control } & \\
\cline { 2 - 5 } & No. & $\%$ & No. & $\%$ & \\
\hline Low serum Vitamin A level & 23 & $45.1 \%$ & 3 & $9.7 \%$ & 0.001 \\
\hline Low serum Vitamin D level & 18 & $35.3 \%$ & 4 & $12.9 \%$ & 0.026 \\
\hline Low serum Zinc level & 31 & $60.8 \%$ & 10 & $32.3 \%$ & 0.015 \\
\hline
\end{tabular}

Table 2. Comparison of serum vitamin A, vitamin D and zinc values in study groups

\begin{tabular}{|l|l|l|l|l|l|l|}
\hline & Group & N & Mean & SD & SEM & P value \\
\hline \multirow{2}{*}{ Vitamin A $(\mu \mathrm{g} / \mathrm{dl})$} & Case & 51 & 17.08 & 10.53 & 1.475 & $<0.001$ \\
\cline { 2 - 7 } & Control & 31 & 42.98 & 21.46 & 3.855 & \\
\hline \multirow{2}{*}{ Vitamin D $(\mathrm{ng} / \mathrm{ml})$} & Case & 51 & 13.91 & 2.99 & 0.419 & $<0.001$ \\
\cline { 2 - 6 } & Control & 31 & 19.38 & 7.83 & 1.407 & \\
\hline \multirow{2}{*}{ Zinc $(\mu \mathrm{g} / \mathrm{dl})$} & Case & 51 & 61.51 & 13.84 & 1.938 & $<0.001$ \\
\cline { 2 - 6 } & Control & 31 & 74.60 & 17.30 & 3.107 & \\
\hline
\end{tabular}


Table 3. Serum vitamin A, Vitamin D and zinc levels according to severity of ALRI

\begin{tabular}{|c|c|c|c|}
\hline & $\begin{array}{l}\text { Severe Pneumonia } \\
(n=30)\end{array}$ & $\begin{array}{l}\text { Pneumonia } \\
(n=21)\end{array}$ & P value \\
\hline \multicolumn{3}{|c|}{ Serum vitamin A level } & \multirow[t]{3}{*}{0.788} \\
\hline Normal & $16(53.3 \%)$ & $12(57.1 \%)$ & \\
\hline Low & $14(46.7 \%)$ & $9(42.9 \%)$ & \\
\hline \multicolumn{3}{|c|}{ Serum Vitamin D level } & \multirow[t]{3}{*}{$0.042 *$} \\
\hline Normal & $16(53.3 \%)$ & $17(80.9 \%)$ & \\
\hline Low & $14(46.7 \%)$ & $4(19.1 \%)$ & \\
\hline \multicolumn{3}{|c|}{ Serum zinc level } & \multirow[t]{3}{*}{0.193} \\
\hline Normal & $14(46.7 \%)$ & $6(28.6 \%)$ & \\
\hline Low & $16(53.3 \%)$ & $15(71.4 \%)$ & \\
\hline
\end{tabular}

Table 4. Comparisons of Mean ( \pm 1 SD) serum level of vitamin A, vitamin $D$ and zinc in severe pneumonia and pneumonia

\begin{tabular}{|c|c|c|c|}
\hline & $\begin{array}{l}\text { Severe Pneumonia } \\
\mathbf{n}=\mathbf{3 0} \\
\text { Mean }( \pm 1 \text { SD })\end{array}$ & $\begin{array}{l}\text { Pneumonia } \\
\text { n=21 } \\
\text { Mean }( \pm \text { 1 SD }) \\
\end{array}$ & p value \\
\hline Vitamin A & $14.00(5.84)$ & $21.49(13.90)$ & $0.011 *$ \\
\hline Vitamin D & $13.62(2.93)$ & $14.31(3.10)$ & 0.425 \\
\hline \begin{tabular}{|l|} 
Zinc \\
\end{tabular} & $63.37(14.74)$ & $58.86(12.30)$ & 0.257 \\
\hline
\end{tabular}

\section{DISCUSSION}

In eastern part of India, we found a significant association between vitamin A, Vitamin D and zinc status and hospitalization for ALRI in a group of children aged less than 5 years. In our study, there was male predominance with a male to female ratio of 1.3:1. This was similar to other studies (Ibraheemet al., 2014; Larkin et al., 2014; Mahalanabiset al., 2004; Ways et al., 2003) ${ }^{7,9,10}$ In our study, socioeconomic status of study populations was homogenous $(\mathrm{p}=0.835)$. Most of cases and controls belonged to lower, upper lower class according to modified Kuppuswamy's Socioeconomic Scale. In our study, 45.1\% children had low serum vitamin $\mathrm{A}$ and among control group, only $9.7 \%$ children had low serum vitamin A levels. There was significant difference of serum vitamin A levels between case and control $(\mathrm{p}=0.001)$. In our study, total $45.09 \%$ had low serum vitamin A level $(<11.3 \mu \mathrm{g} / \mathrm{dl})$ and $72.5 \%$ of ALRI cases had less than $20 \mu \mathrm{g} / \mathrm{dl}^{14}$. Buyukgebizet al., (1990)

Table 5. Comparisons of present study with other studies

\begin{tabular}{|c|c|c|c|c|c|c|c|c|}
\hline Parameters & Present Study & \begin{tabular}{|l|} 
Buyukgebizet \\
al., 1990
\end{tabular} & $\begin{array}{l}\text { Kucukbay } \\
\text { et al.,1997 }\end{array}$ & $\begin{array}{l}\text { Roth } \\
\text { et al., } 2010\end{array}$ & $\begin{array}{|ll|}\text { Ways } & \text { et } \\
\text { al., } 2003 & \\
\end{array}$ & $\begin{array}{l}\text { Ibraheemet } \\
\text { al., 2014 }\end{array}$ & \begin{tabular}{|l|} 
Arica \\
et al., 2011
\end{tabular} & $\begin{array}{l}\text { Shakur et } \\
\text { al., } 2003\end{array}$ \\
\hline Age & $1-60 \mathrm{mo}$ & $6 \mathrm{mo}-6 \mathrm{yr}$ & $6 \mathrm{mo}-6 \mathrm{yr}$ & $1-18 \mathrm{mo}$ & $2 \mathrm{mo}-5 \mathrm{yr}$ & $2-60 \mathrm{mo}$ & $<24$ mo & $6-60 \mathrm{mo}$ \\
\hline \multicolumn{9}{|c|}{$\operatorname{Vitamin} \mathbf{A}(\mu \mathrm{g} / \mathrm{dl})$} \\
\hline Cases* & $17.08 \pm 10.53$ & $24.1 \pm 3.8$ & $51.66 \pm 8.10$ & - & - & - & - & - \\
\hline \begin{tabular}{|l|} 
Control* \\
\end{tabular} & $42.98 \pm 21.46$ & $33.6 \pm 4.7$ & $58.14 \pm 9.07$ & - & - & - & - & - \\
\hline \multicolumn{9}{|c|}{ Vitamin D (ng/ml or $\mathrm{nmol} / \mathrm{L})$} \\
\hline Case* & $13.91 \pm 2.99$ & - & - & $\begin{array}{l}29.1 \pm 17.2 \\
\mathrm{nmol} / \mathrm{L}\end{array}$ & $\begin{array}{l}\text { Geometric mean } \\
9.12 \mathrm{ng} / \mathrm{ml}\end{array}$ & - & - & - \\
\hline Control* & $19.38 \pm 7.83$ & - & - & $\begin{array}{l}39.1 \pm 9.4 \\
\mathrm{nmol} / \mathrm{L}\end{array}$ & $\begin{array}{l}\text { Geometric } \\
\text { mean15.36ng/ml }\end{array}$ & - & - & - \\
\hline \multicolumn{9}{|l|}{ Zinc $(\mu \mathrm{g} / \mathrm{dl})$} \\
\hline Case* $^{*}$ & $61.51 \pm 13.84$ & - & - & - & - & $18.7 \pm 11.8$ & $24.47 \pm 12.41$ & $90 \pm 51$ \\
\hline Control* & $74.60 \pm 17.30$ & - & - & - & - & $53.1 \pm 18.5$ & $54.96 \pm 29.99$ & $176 \pm 98$ \\
\hline
\end{tabular}

In India, high infant mortality rate and high incidence of infections especially acute respiratory infections and diarrhea are major child health problems. From this point of view, we aimed to investigate the serum in vitamin A levels of children who have acute respiratory infections. According to our results, subclinical vitamin A deficiency may be an important health problem in this part of India, other cause of low serum vitamin A level may be socio-economic status, poor feeding and over-crowding. We also found a significant association between low vitamin D status and hospitalization for ALRI in a group of infants and children younger than 5 years. A causal role of vitamin D status in ALRI that endogenous synthesis of a host antimicrobial peptide (LL37 ) is stimulated by the activation of the vitamin D receptor by 1 , $25(\mathrm{OH})$ D2 in monocytes and respiratory epithelial cells. Upregulation of LL-37 in tracheal secretions during lower respiratory tract infections in infants further suggests its potential role in innate defences against ALRI.In vitro studies (Rockettet al., 1998; Cantorna et al., 2000 and Pichleret al., 2002) and clinical studies of rickets (Lubaniet al., 1989; Banajehet al., 1997 and Muheet al., 1997) support a role for vitamin $\mathrm{D}$ in protecting against infectious diseases. It seems more likely that poor vitamin D status was a causal factor that increased severe ALRI than that ALRI induced low serum 25OHD3. In observed that $64 \%$ of their children with ALRIs had low serum vitamin A in cases of ALRI was $17.08 \mu \mathrm{g} / \mathrm{dl}$ and in control was 42.98 $\mu \mathrm{g} / \mathrm{dl}$; the difference being statistically significant $(\mathrm{p}<0.001)$. In other studies ( Buyukgebizet al., 1990, Kucukbayet al., 1997) the authors also observed significant difference between case and control group with respect to mean serum vitamin A levels $(\mathrm{p}<0.001)$. In the study of Buyukgebizet al., (1990), the mean serum level of vitamin A in case of ALRI was $24.1 \mu \mathrm{g} / \mathrm{dl}$ while Kucukbayet al., (1997), reported amean level of $51.66 \mu \mathrm{g} / \mathrm{dl} .^{14,1}$

In present study, among cases, $35.3 \%$ children had low serum vitamin $\mathrm{D}$ while the corresponding figure was $12.9 \%$ for controls. The mean serum level of vitamin D in cases and control group were, 13.91 $( \pm 2.99) \mathrm{ng} / \mathrm{ml}$ and $19.38( \pm 7.83) \mathrm{ng} / \mathrm{ml}$, respectively; the difference being statistically significant $(\mathrm{p}<0.001)$. Other authors (Roth et al., 2010 and Wayseet al., 2003.) had similar observations. ${ }^{6,13}$ Not all researchers found a decrease in ALRIs withincreased vitamin D levels. Roth et al., 2009 conducted a study in Alberta, Canada, and did not find a significant difference in vitamin D deficiency between 64 cases of ALRI and 65 control subjects without a history of hospitalization for ALRI. McNally et al., (2009) also found no difference in mean vitamin D levels between 105 children with ALRI and 92 control children in Saskatchewan, Canada. ${ }^{6,13}$ In our study, among cases, $60.8 \%$ children had low levels of serum zinc. Among controls, $32.3 \%$ children had low serum zinc. The mean serum level of zinc in cases of ALRI was 61.51 $\mu \mathrm{g} / \mathrm{dl}$ and in control group, $74.60 \mu \mathrm{g} / \mathrm{dl}$. There was significantly low level of zinc in case of ALRI as compared to the control group ( $p$ $<0.001)$. Similar were the observations of Ibraheemet al., (2014); Arica et al., (2011) and Shakur et al., (2004).,

Though we observed higher percentage of low values of Vitamin A, Vitamin D and Zinc in severe cases of ALRI, it was statistically significant for the Vitamin D levels only $(\mathrm{p}=0.042)$. The mean level of serum vitamin A was also significantly low in case of severe pneumonia while the mean levels of Vitamin D and zinc were comparable. Table 5 compare the conclusion of present to other studies. vitamin A less than $20 \mu \mathrm{g} / \mathrm{dl} .{ }^{14}$ In present study, mean serum level of

our study we also found significant correlation of serum vitamin D level to severity of ALRIs. There was other case-control study from India, where the authors found that serum $25(\mathrm{OH}) \mathrm{D}$ levels $>9 \mathrm{ng} / \mathrm{ml}$ was associated with a significantly lower risk of severe ALRI $(\mathrm{p}<001)$. In a study of 152 children younger than 59 months of age with pneumonia at Yemen, vitamin D deficiency was an independent predictor of persistent hypoxemia for children admitted with pneumonia (Banajehet al., 2009).

In our study there was a significant association between vitamin D status and early childhood ALRI in this region of India. These findings strengthen the rationale for prospective studies to establish the determinants of vitamin $\mathrm{D}$ status in tropical regions and randomized controlled trials aimed at determining whether feasible and safe interventions that improve vitamin D status yield reductions in the burden of childhood ALRI in resource-poor communities. In the current study we also found, significantly higher prevalence of low serum zinc status in children with ALRI, which may be clearly attributed to a pre-existing zinc deficiency state with its attendant negative effects on the immune status.Zinc is an essential factor for the development and sustenance of the human immune system which is 
recruited during an infection to prevent pathogens from gaining access into cells.Clearly, all the anti-infective deployment of this trace element may further deplete the zinc levels during an episode of ALRI. It has also been suggested that the low serum zinc levels identified during ALRI is mediated by interleukins and tumor necrosis factoralpha $(\mathrm{TNF}-\alpha)$ as part of an infection-related set of metabolic response known as acute phase reaction. Soserum concentration of zinc decreases sharply in inflammation and infection and may reflect a normal protective mechanism because, lower concentration of zinc are associated with both optimal phagocytic function and depressed microbial virulence.Hence, zinc supplementation in cases of ALRI would be desirable. The finding of low levels of vitamin A, vitamin D and zinc in cases of ALRIs suggest that supplementation of these micronutrients may be beneficial in this condition.

\section{CONCLUSION -}

In conclusion, there was a significant association between vitamin A, vitamin D and zinc with early childhood of ALRIs. These findings suggest that feasible and safe interventions that improve these micronutrients status may yield reductions in the burden of childhood ALRI in resource-poor communities. The children with ALRI had lower serum vitamin A, vitamin D and zinc levels than the control and the prevalence of low serum status in children with ALRI is high. Thus, there is a need to determine whether hospitalized children managed for ALRI might benefit from vitamin A, vitamin D and zinc supplementation as an adjunct to treatment as well as post discharge. Limitations of this include, lack of knowledge of the pre-morbid status of the children with ALRI, and low number of patient in our study.

\section{REFERENCES -}

1. Michael S Niederman, Leonard R Krilov. Acute lower respiratory infections in developing countries. Lancet 2013;318:1341-1342.

2. Richard D,Muhilal, MohgaddamNasrin EG et al., Integration of Vitamin A Supplementation with the Expanded Program on Immunization Does Not Affect Seroconversion to Oral Poliovirus Vaccine in Infants.J Nutr 1999;129:2203-2205.

3. Küçükbay H, Yakinci C, Küçükbay FZ, et al., Serum Vitamin A and Beta-carotene Levels in Children with Recurrent Acute Respiratory Infections and Diarrhoea in Malatya. J Trop Pediatr 1997;43:337-340.

4. Swami HM, Thakur JS, Bhatia SPS. Impact of mass supplementation of vitamin A. Indian J Pediatr 2007;74:443-447.

5. Laaksi I, et al., An association of serum vitamin D concentrations $<40 \mathrm{nmol} / \mathrm{L}$ with acute respiratory tract infection in young Finnish men. Am J ClinNutr 2007;86:714-717.

6. Roth DE, Shah R, Black RE, et al.,Vitamin D status and acute lower respiratory infection Roth DE, Shah R, Black RE, et al.,Vitamin D status and acute lower respir.
in early childhood in Sylhet, Bangladesh.ActaPaediatr 2010;99:389-393.

7. Ibraheem RM,Johnson AW, AbdulkarimAishatu.Serum zinc levels in hospitalized children with acute lower respiratory infections in the north-central region of Nigeria. Afr Health Sci 2014;14:136-142.

8. LakhanpaulMonica, Atkinson Maria, Stephenson Terence. Community acquired pneumonia in children. A clinical update. Arch Dis Child EducPract2004;89:ep29-ep34.

9. Ross AC, ME Shils, M Shike, et al., Vitamin A and Carotenoids. In Modern Nutrition in Health and Disease. 10th ed. Philadelphia, Lippincott Williams and Wilkins 2006;351375 .

10. Institute of Medicine, Food and Nutrition Board. Dietary Reference Intakes for Calcium and Vitamin D. Washington, DC: National Academy Press, 2010.

11. Zorbas YG, Kakuris KK, Neofitov IA, et al., Zinc utilization in zinc-supplemented and unsupplemented healthy subjects during and after prolonged hypokinesis. Tr Elem Electro 2008;25:60-68.

12. Mahalanabis D, Lahiri M, Paul D, et al., Randomized, double-blind, placebo-controlled clinical trial of the efficacy of treatment with zinc or vitamin A in infants and young children with severe acute lower respiratory infection. Am J ClinNutr 2004;79:430-436.

13. Wayse V, Yousafzai A, Mogale K et al.,Association of subclinical vitamin D deficiency with severe acute lower respiratory infection in Indian children under 5 years.Eur $\mathrm{J}$ ClinNutr2004;58:563-567.

14. Buyukgebiz B, Ozalp I,Oran O. Investigation of Serum Vitamin A Levels of Children who had a History of Recurrent Diarrhoea and Acute Respiratory Infections in Ankara.J Trop Pediatr1990;36:251-255.

15. Küçükbay H, Yakinci C, Küçükbay FZ, et al., Serum Vitamin A and Beta-carotene Levels in Children with Recurrent Acute Respiratory Infections and Diarrhoea in Malatya. J Trop Pediatr 1997;43:337-340.

16. McNally JD, Leis K, Matheson LA, Karuananyake C, Sankaran K, Rosenberg AM. Vitamin D deficiency in young children with severe acute lower respiratory infection.PediatrPulmonol 2009:44:981-978.

17. Arica Secil, Arica Vefik, Dag Hüseyin, et al., Serum zinc levels in children of 0-24 months diagnosed with pneumonia admitted to our clinic. Int J ClinExp Med 2011:4:227-233.

18. Shakur Salim, Malek M.A., BanoNasreen, et al., Zinc Status in Well Nourished Bangladeshi Children Suffering from Acute Lower Respiratory Infection. Indian Pediatr 2004;41:478-481. 